\title{
Convergence
}

\section{The Making of the Canning Stock Route Project and Yiwarra Kuju Exhibition}

\section{CARLY DAVENPORT ACKER}

-INTRODUCTION

Back at home in Martu country, we keep telling people our stories and our culture, to anthropologists and archaeologists mainly, people who are coming and critiquing Jukurrpa (Dreamtime cosmology). And I think that is where we need to be careful. We need to tell the same things in art todaythat we are living the Jukurrpa. It's not for outsiders to critique it, but we are completely immersed in it. And that's how, you know, people from the outside should see that too.

Curtis Taylor, $2012^{1}$

Curtis Taylor's message conveys how important it is that Aboriginal people participate, decide, own and control the telling of their stories and histories,

\section{ISSN 1837-8692}

Cultural Studies Review 2015. @ 2015 Carly Davenport Acker. This is an Open Access article distributed under the terms of the Creative Commons Attribution 4.0 Unported (CC BY 4.0) License (https://creativecommons.org/licenses/by/4.0/), allowing third parties to copy and redistribute the material in any medium or format and to remix, transform, and build upon the material for any purpose, even commercially, provided the original work is properly cited and states its license. 
particularly through digital media. It is this necessary but complex aspiration that underlies the processes, practices and successes of the Ngurra Kuju Walyja (One Country, One People) Canning Stock Route Project ${ }^{2}$ and 'Yiwarra Kuju' exhibition. The core methodology of this multilayered arts and cultural project was to provide artists, elders and young people the means to share their stories in a way that reflected the social logic, historical sweep and cultural networks of the Western Desert. This resulted in more than two hundred and forty Aboriginal people and over one hundred non-Aboriginal people being involved in the project. It is the processes generated by the Canning Stock Route Project and the participation that made the 'Yiwarra Kuju' exhibition possible that I wish to explore in this essay. In keeping with the additive, evolving nature of the original project, this essay draws on a presentation made at the Same but Different: Experimentation and Innovation in Desert Arts inaugural forum in 2012. At that forum Curtis Taylor, a young Martu filmmaker, and I assembled some of the many stories that illustrated the project's aims.

-A Western Desert PROJect

The Canning Stock Route Project is about community, collaboration and reconciliation. It involves seventeen Aboriginal communities across the Pilbara, Midwest, Goldfields and Kimberley regions of Western Australia. The story is for all of us, for communities all across Australia, Aboriginal people telling our story and our history to the world.

It's about two-way learning, black and white, urban and remote, Aboriginal and non-Aboriginal. It involved 58 kinds of workshops in Country with young people and old people, with emerging and established artists and art centres. It gave all the different communities right across the desert a chance to shine. This has never happened before. The project gave us a chance to listen to each other, work and learn from each other.

Curtis Taylor, $2010^{3}$ 


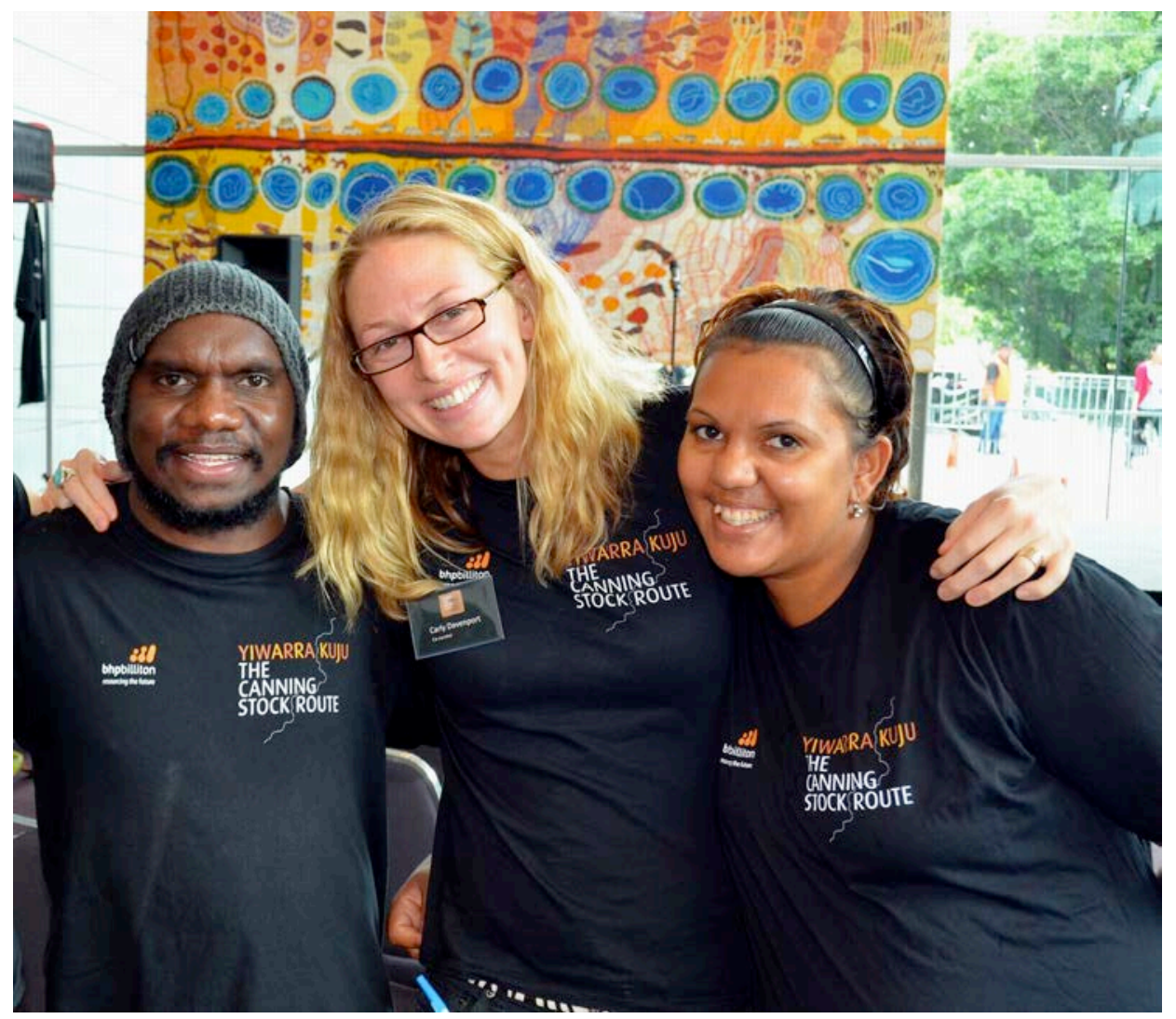

Image 1: Curtis Taylor, Carly Davenport Acker and Kat Sorenson at Yiwarra Kuju exhibition, Perth 2011 (photograph: T. Acker (C) FORM)

This quote from Curtis Taylor introduces the scope of a project that covered a considerable portion of Western Australia, physically and culturally. Following a proposal made by Tim Acker and I to FORM, a Perth-based cultural organisation, the project started in 2006.4 The initial project aims were modest: to explore the artistic and family links between some of the Western Desert's Aboriginal art communities. ${ }^{5}$ However, the project grew into a substantial alliance of art and cultural centres from throughout Western Australia's remote regions. The organisations included Mangkaja Arts and Kimberley Aboriginal Law and Culture Centre (Fitzroy Crossing), Ngurra Artists (Wangkajungka), Yulparija Artists (Bidyadanga via Short St Gallery), Paruku Indigenous Protected Area (Mulan), Martumili Artists (Newman, Punmu, Parnngurr, Nullagine, Jigalong and Kunawarritji), Papunya Tula Artists (Kiwirrkurra), Warlayirti Artists (Balgo), Kayili Artists (Patjarr), and Birriliburu Artists (Wiluna). The premise of the project was founded on a remote/regional arts 


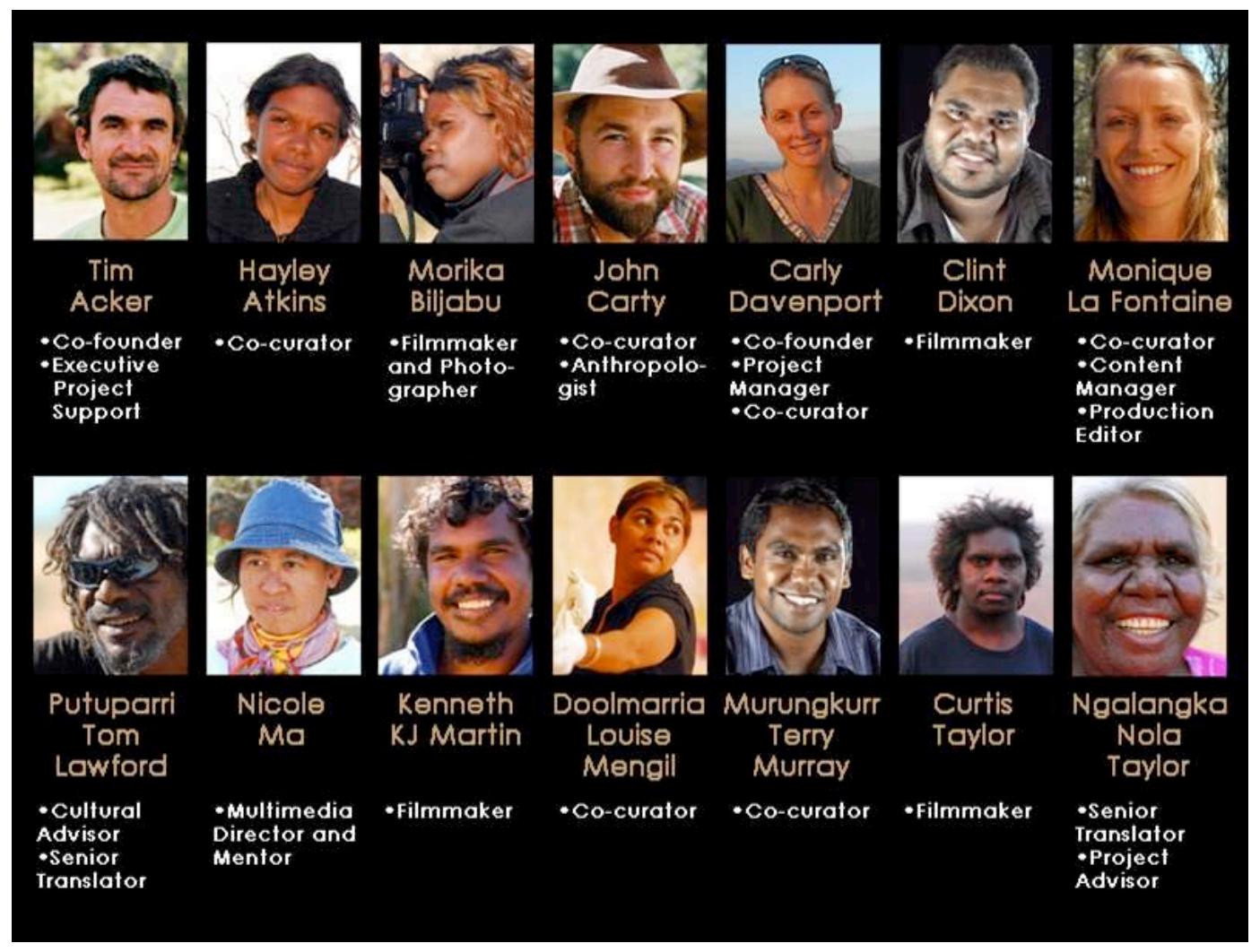

Image 2: Project and Exhibition Project team (photograph @ FORM)

development and community outreach program and its main aim was to produce an exhibition and publication that explored the complex history of the Canning Stock Route. 6

From the beginning, the invitation to artists to participate stretched beyond a standard creative brief towards a deeper art and cultural history analysis, involving recording family connections and mapping these associations across the deserts. This was a major incentive for artists, as it gave them the opportunity to share their personal histories locally, regionally and with national and global audiences, on their own terms. It became an extremely popular topic on the bush telegraph. Once the project had gathered momentum, we were approached by other artists wanting to join in and the number involved expanded to 110.

Family kinship was the ecosystem from which the project grew and this guided how resources and activities were directed. Ngarralja Tommy May (Mangkaja artist and senior cultural advisor), Putuparri Tom Lawford (senior translator and cultural advisor) and Murungkurr Terry Murray (co-curator), expressed it thus: 
We're all family. All the stories are about how all the families got scattered across the Western Desert. And at the art centres, we are all related. From Wiluna and Kiwirrkurra and Balgo, Mulan and Martu Country. From Nyarna (Lake Stretch) right down to Wiluna. Our ancestors walked that land. The Canning Stock Route forced all the peoples to different places. But people still talk about their Country and call the names, and we talk about how all the art centres are going to tell their stories. Everybody has that same story. ${ }^{7}$

In the project's first year, its activities focused on artistic and professional development workshops in Country. The first workshop was a carving and traditional tool making bush trip to Jilji Bore in late 2006 with Mangkaja and Ngurra artists. At the end of four industrious days, artist and elder Ned Cox stated he would champion the project in his community, and a video was made with artists singing out to Balgo community for their participation. Additional workshops mirrored Aboriginal artistic cultural expression. They integrated carving, weaving, painting, storytelling, singing and dancing, and experimented in combining traditional and contemporary arts practices.

The most imposing and ambitious artist workshop that the project undertook was an epic return-to-Country trip along the Canning Stock Route in 2007. This sixweek journey generated enormous goodwill across the Western Desert and was the catalyst for many of the exhibition's iconic paintings and much of the oral history.

This artistic journey involved a multidisciplinary, intercultural team of seventeen, who drove from south to north in five $4 \mathrm{WDs}$. This convoy met with nine other vehicles carrying six art centre groups, staff and volunteers, who camped and painted with the central convoy for varying distances. Converging from different directions, a total of sixty artists in fourteen vehicles and charted planes met at Well 33 (Kunawarritji) and drove to Well 36. Here, iconic men's and women's canvases were created on the ground encircling the reeds of Well 36.

The project team stopped at key points along the route and set up longer camps where people could spend time painting their Country in their Country. For some artists it was the first time they had been back to these places since moving to missions and station decades before. For others, this was the last time they would see these places. For young Aboriginal 


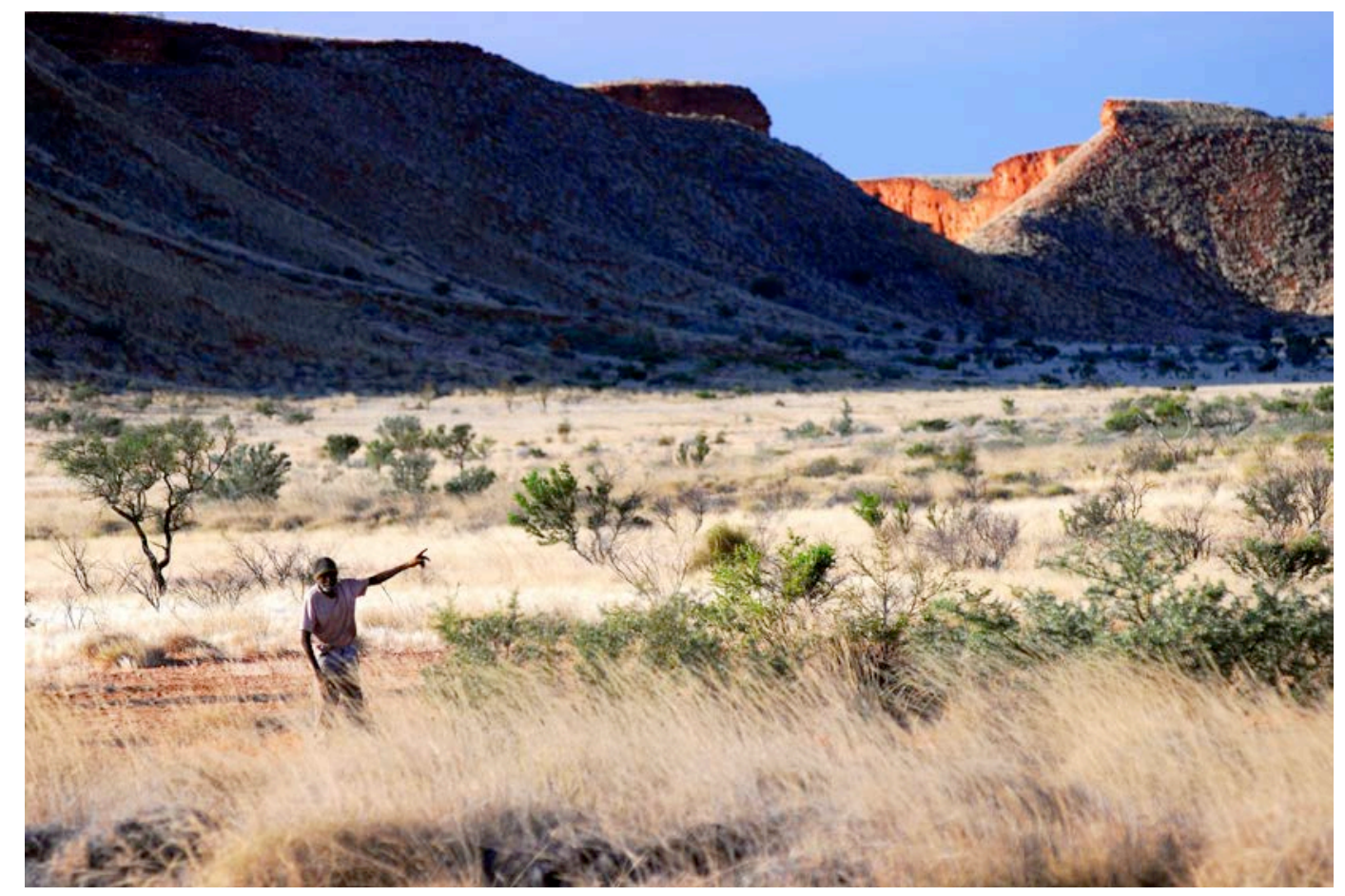

Image 3: Along the Canning Stock Route bush trip, July 2007; this was the last time the late Charlie Wallabi Tjungurrayi would visit his country known as Kaningarra (photograph: T. Acker; @ FORM)

people involved in the project, it was sometimes the first time they had seen their own Country. For everyone involved, these larger gatherings were emotional and galvanising experiences. ${ }^{8}$

Six weeks later at the end of the expedition, the inaugural display of art works was laid out on the beach-like shores of Nyarna (Lake Stretch), near Billiluna community for a few hours. It was an ephemeral exhibition, yet perhaps most the compelling in the whole project. This trip certainly opened up the character and shape of what the project and its major exhibition would become.

At the trip's completion, project staff realised they would need considerable time to collate all the stories and continue the consultations with artists to research the dizzying interconnections that define the Western Desert. We would also need to return to communities to ensure transcriptions were correct and that material could be assessed and cleared by those with the cultural authority to do so. This was achieved by engaging a growing team of Aboriginal emerging curators and multimedia practitioners and cultural advisors. 


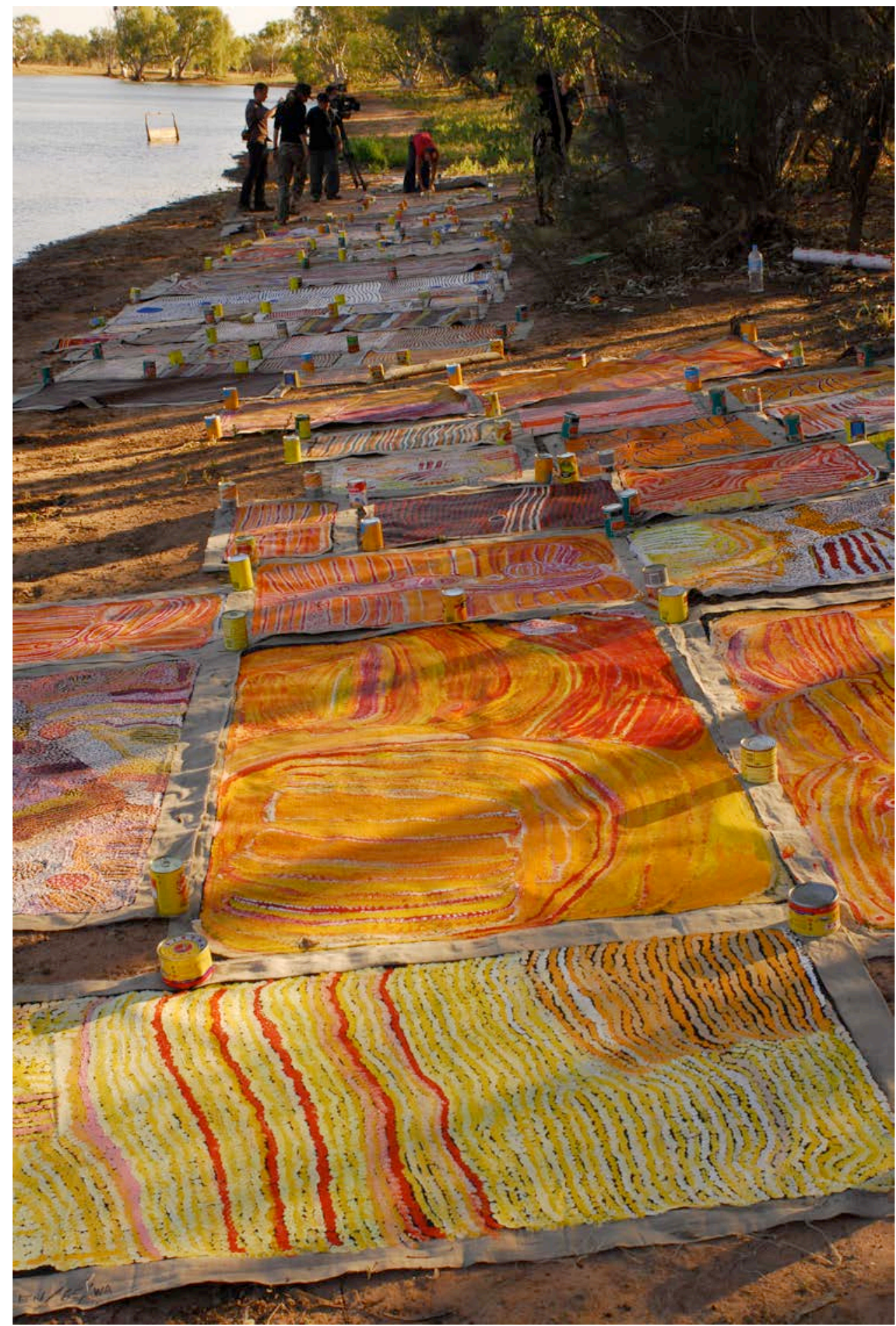

Image 4: Works produced along the Canning Stock Route and laid out at Lake Stretch, Billiluna August 2007 (photograph: T. Acker; ๑ FORM) 


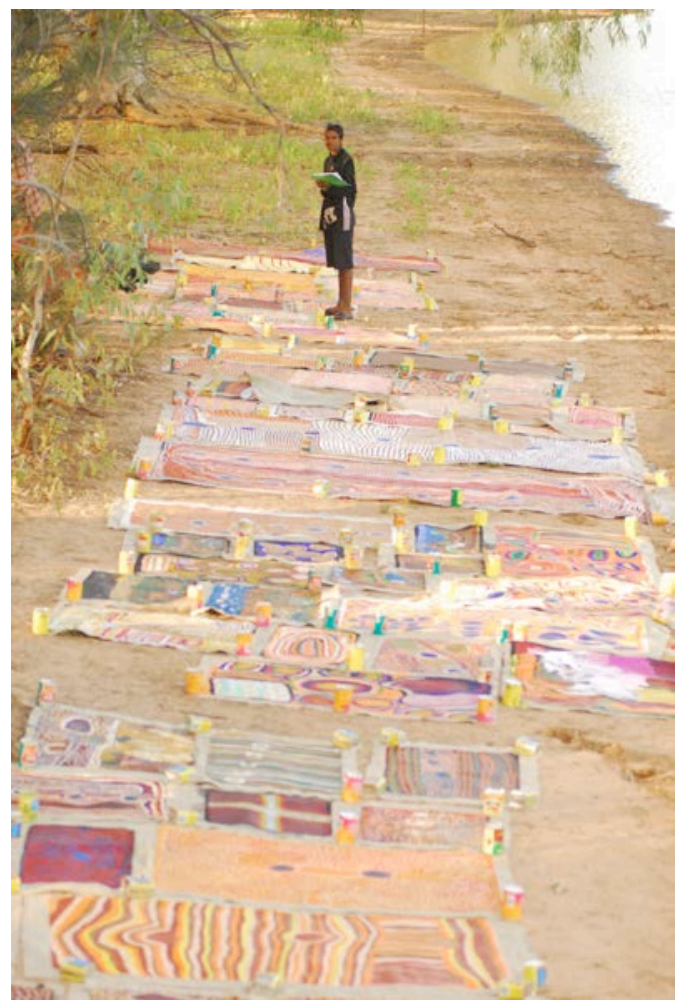

Image 5: Co-curator of Yiwarra Kuju Hayley Atkins with works produced along the Canning Stock Route and laid out at Lake Stretch, Billiluna, August 2007 (photograph: T. Acker; @ FORM)

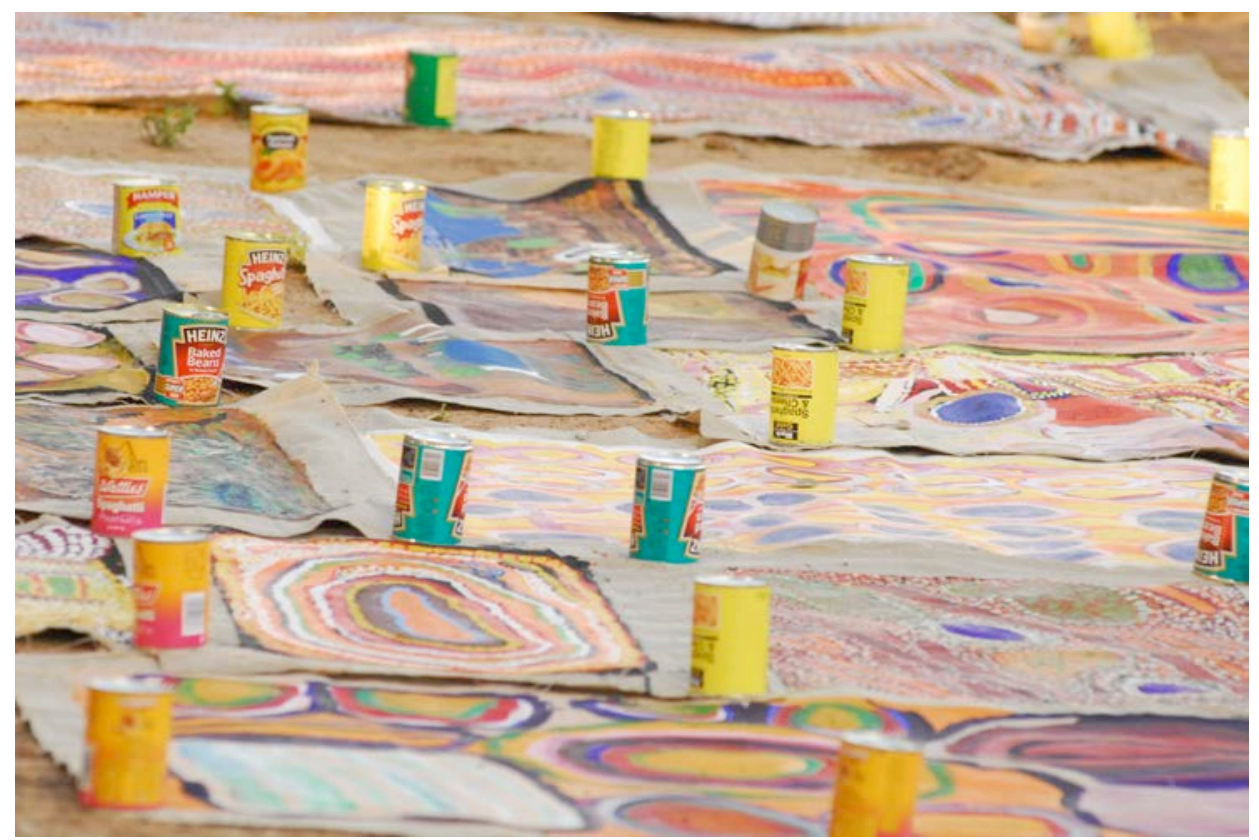

Image 6: Works held down by leftover food tins laid out at Lake Stretch, Billiluna, August 2007 (photograph: T. Acker; @ FORM) 
-A CITY EXHIBITION

From the very outset, art was the connector, the invitation for both artists and audiences to engage. More than two hundred works of art were produced inCountry and built incrementally through the many multiarts development workshops and visits to the art centres. Encasing this body of works was a repository of over one hundred and twenty oral histories, one hundred and sixty new media short films and thousands of photographs. ${ }^{9}$ A collaborative curation process was used to shape this raw material into a compelling collection. The team included senior curator and mentor Wally Caruana (2007-2008) together with emerging curators Hayley Atkins, Terry Murray and Louise Mengil, and Dr John Carty, Monique La Fontaine and I. The final Canning Stock Route Collection comprised 130 works of art: paintings (on canvas, board and paper), carvings, fibre works and ceremonial wear. We intended to keep the works and documentary material together, like a time capsule, so it was important to find the right home for this collection, an institution whose values matched our own. ${ }^{10}$

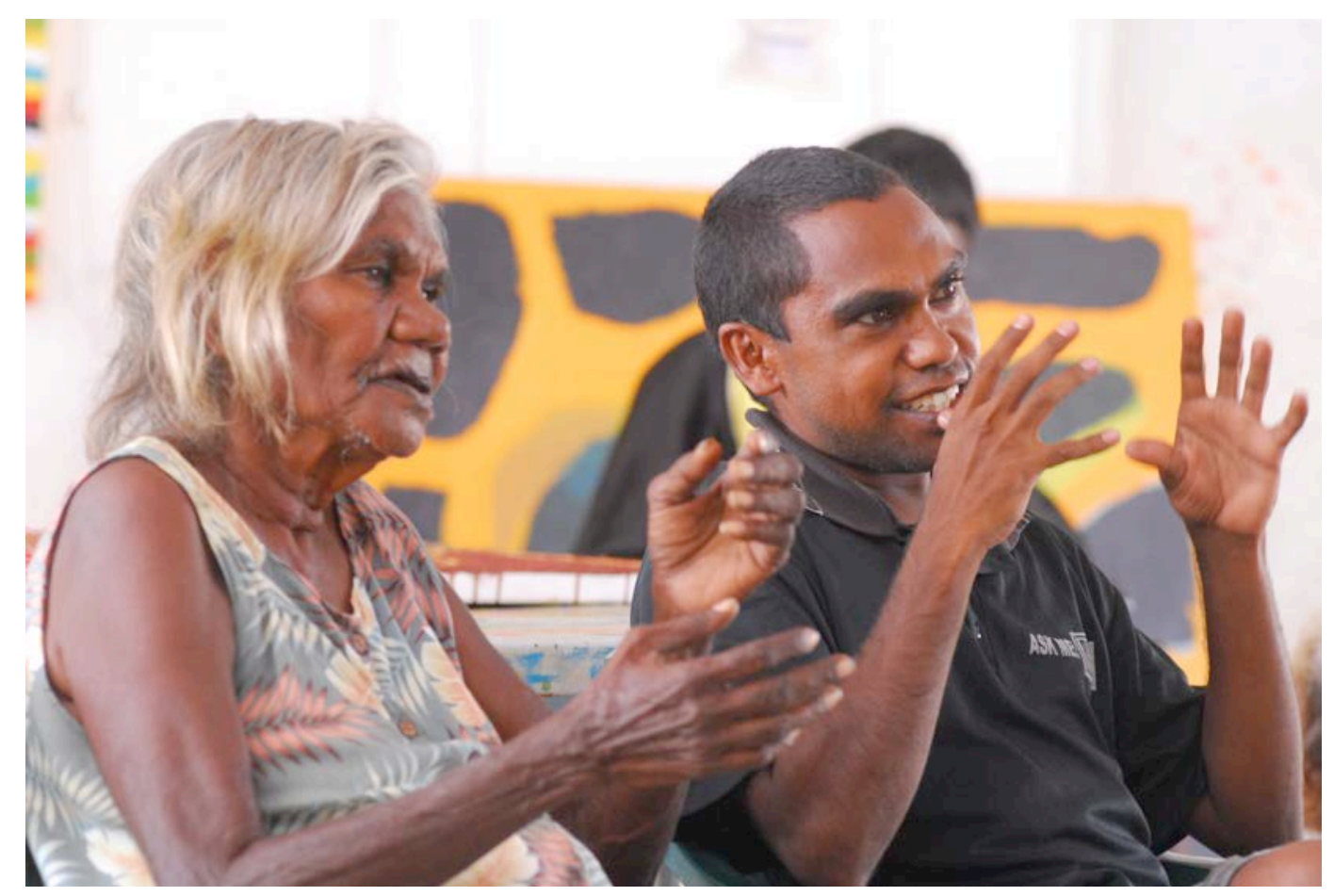

Image 7: Artist Daisy Andrews and co-curator Terry Murray, Mangkaja 2008 (photograph: T. Acker; (c) FORM) 
In late 2008, ironically right at Christmas, the National Museum of Australia (NMA) stepped in to acquire the works, which would be known as the Canning Stock Route Collection, to be part of the National Historical Collection. To everyone's relief, artists were paid for their art works. Building this body of work had taken almost two years as each work was collated and documented and the connections mapped between artists, country and history from hundreds of hours of footage, tape and interviews. ${ }^{11}$ Following NMA director Craddock Morton's visit in 2008 to Perth's Black Swan Theatre Company, where he was guided by emerging curators Louise Mengil and Hayley Atkins on a tour through all the works laid out on the floor, he deemed the collection a 'national treasure':

The National Museum of Australia regards this collection as one of truly national significance, providing a unique archive of Indigenous social and cultural histories. It is an important addition to the nation's heritage and history collections. ${ }^{12}$

At this time, the NMA endorsed FORM's research processes and confirmed they would contribute to the significant financial and human resources, facilities and technologies to fully develop the collection into an exhibition. This institutional partnership provided essential ballast for the project, as the team geared up to take on the challenge of curating the seven hundred square metre travelling exhibition that would become known as 'Yiwarra Kuju (One Road)'.

Dr Michael Pickering, then Aboriginal and Torres Strait Islander Program Director at the NMA and a champion for 'Yiwarra Kuju', referred to the art collection as 'being the tip of the iceberg' with the real mass of content hidden 'underneath the waterline'.13 Pickering understood the project's complexity, having spent time with the team in the Kimberley, where he had seen the potential of utilising the extensive research and digital documentation to tell a truly encompassing story. He witnessed the relationships the team had with the communities and encouraged the continuation of the first-person representation as the best means to directly engage audiences; with them gaining a deeper sense of an artwork's cultural and contextual production. ${ }^{14}$ This paralleled the project team's vision and intention to find innovative ways of bringing the Country and its peoples to the capital.

The project and its exhibition were founded and directed by two primary motivations. First, an artist's history must be shared locally with families for present 
and future access and second, that artist's history and culture must be shared with global audiences. The project's curatorial and communication tone stems from Aboriginal values of walyja (family), ngurra (Country/ home) and Jukurrpa.

These values were discussed as part of a communications design workshop held in Perth in early 2008 with the design company Glasfurd and Walker who assisted the team to define the project's 'brand' and identity, 'mood' and art direction. ${ }^{15}$ We could then readily transfer an understanding of the complex cultural information and purpose of the project to external consultants, funding partners and public audiences to ensure that the spirit and energy of Western Desert people could be integrated into every aspect of the production. Later in 2009, this logic aided our growing partnership and communication with the NMA's various departments and our ability to clearly convey the values and messages important to remote and regional participants. These values remained a consistent compass informing Yiwarra Kuju's curatorial structure, exhibition design and marketing.

With Pickering's close guidance, the project team moved to curating Yiwarra Kuju and engaged with the NMA's multiple production teams (exhibition development, publishing and education departments, digital media unit), and an array of exhibition development consultants. ${ }^{16}$ The collaboration with exhibition designer Susan Freeman and her team (Freeman Ryan Design or FRD) guided the curatorial team's sometimes wildly ambitious dreams into reality. ${ }^{17}$ Parallel to this process, the NMA's publishing department guided the way for team members to write and curate the catalogue which operated as a thematic blueprint for the exhibition text. The curatorial team then worked with the education department to construct the education kit and children's trail.

It's not my intention in this essay to describe specific conceptual or methodological innovation of the show's curatorial aspects. This has been excellently captured by Biddle, Fontaine and Carty who have, individually, analysed Yiwarra Kuju's addressing of Australian history, its digital media archive of One Road (Yiwarra Kuju) and curation.18 Biddle asserts:

The sheer size of the exhibition alone is testament to the screaming fact of Aboriginal presence in the now. This is not bite-sized history dumbeddown to a single correct position nor recognisable rhetorical posturing but 


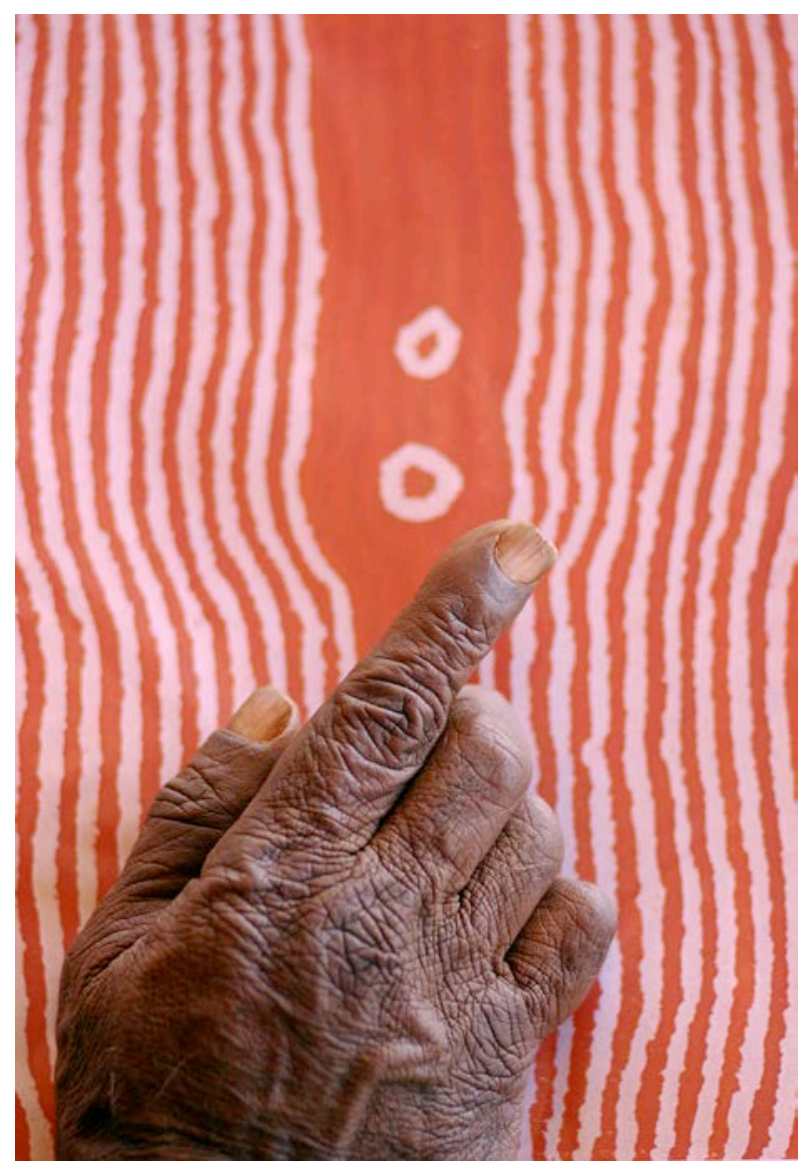

Image 8: Warlayiti artist Helicopter Tjungurrayi refers to his painting Natawalu, 2007, acrylic on linen, 76.9 x $53.4 \mathrm{~cm}$ (photograph: T. Acker; (C FORM)

complicated, subtle and ambiguous history in the making. Yiwarra Kuju does not only call attention to the highly selective versions of official history and those excluded from it. It equally insists upon the unique specificity of traditional Western Desert archive-of Aboriginal forms of historiography-in its own terms. ${ }^{19}$

And similarly, Carty articulates, the exhibition 'needs to be understood at the intersection of histories: the history of contemporary Aboriginal art in Australia, the history of Australia and the history of the National Museum'.20

This was not a fine art show dropped into a social history museum. Nor was it a museum show jazzed up by the inclusion of fine art. It was not an exhibition that included or displayed Aboriginal art, but rather an exhibition that strove to illuminate what that art was about. Every 
curatorial decision in the show was orientated towards letting those paintings resonate or communicate with their audience on terms defined by the people who made them. ${ }^{21}$

-BEYOND PAINTINGS

While the making, documenting and exhibiting of art is at the centre of the project's work, in many ways those elements that were not about art were the real achievement of the project and its ability to engage both communities and audiences. These include the education, employment, training and legacy components.

Accessing relevant and realistic employment in remote communities is a significant issue. And while the creative sector cannot address this on a large scale, creative and cultural work has major traction in these areas. In acknowledging this, the project instigated an employment and mentoring program. This program recruited seven young Aboriginal people from across the project's catchment area and employed them throughout the expanding content development and approval processes, teaming them up with mentor professionals such as Nicole Ma (film) and Wally Caruana (curating) and an array of specialists. Using a flexible, contract employment framework, the program connected with the same people across the years. The model has encouraged engagement of remote area Aboriginal and Torres Strait Islander curators; other Western Australian examples to use a similar model include the Wesfarmers and National Gallery of Australia's Indigenous Arts Leadership program, 'Revealed Emerging Aboriginal Artists' exhibition (Department of Culture and the Arts) and 'Desert River, Sea: Kimberley Art, Then and Now' by the Art Gallery of Western Australia. The model also contributed to the NMA's policy and Indigenous staff network program. The challenge was funding it. The model was granted pilot funding for one year by the Department of Culture and the Arts, which, in partnership with FORM, was extended for three years, until the exhibition's launch.

The ongoing social, cultural and economic returns to the art centres, the project's focus on intergenerational exchange and profile building for the artists and, of course, the artists, Aboriginal team members and cultural leader's personal and professional experiences as participants and contributors, are more intangible 


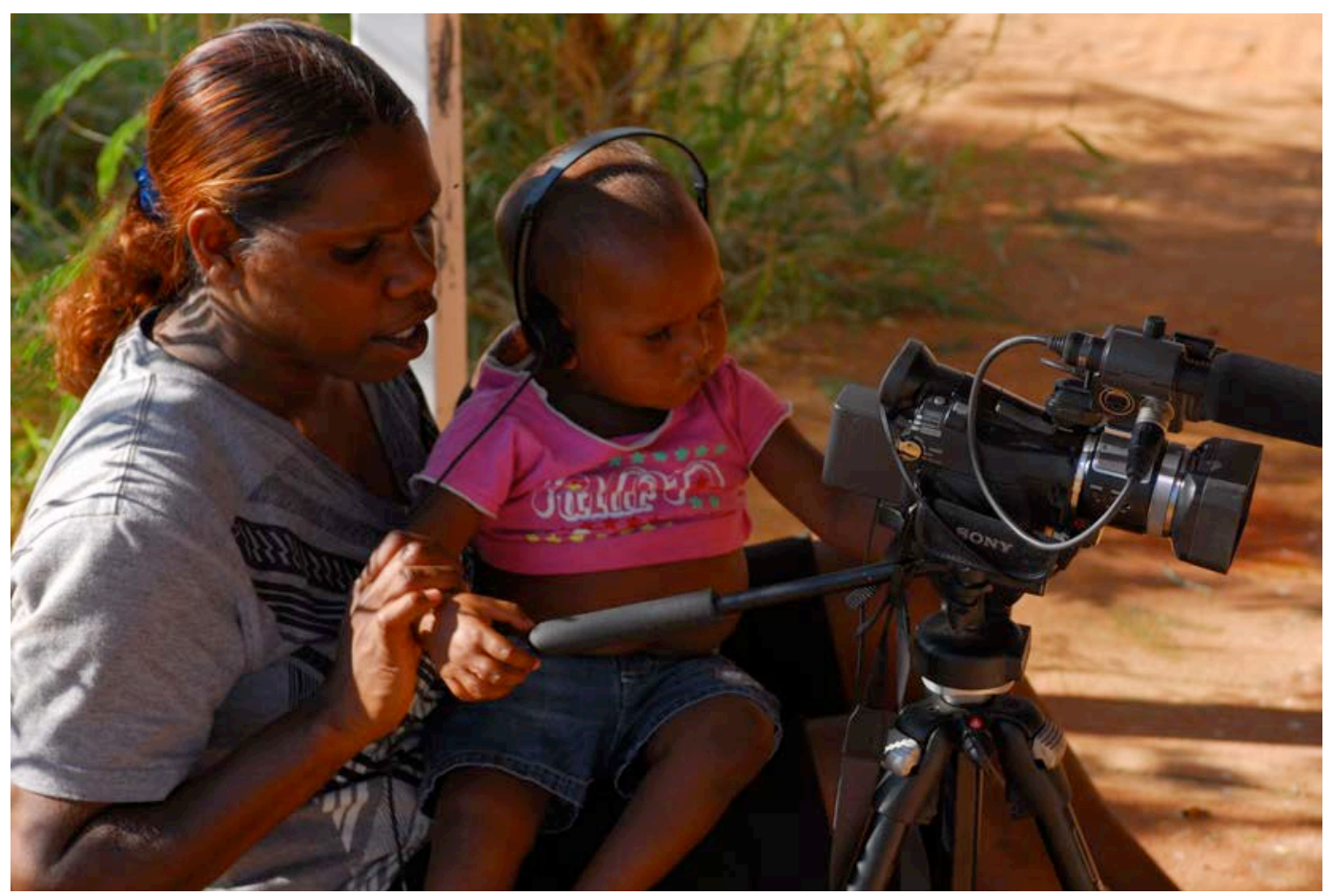

Image 9: Emerging filmmaker Morika Biljabu and niece, Punmu 2009 (photograph: C. Davenport Acker; (c) FORM)

examples of success, but are evident in their long-term willing engagement with the project and the exhibition. A more recent 2014 example of the ongoing relevance of the project to traditional owners is the use of project content by the Central Desert Land and Community (CDLC) organisation for interpretative signage along the Stock Route to educate travellers and tourists. ${ }^{22}$

The project always aimed to engage and educate audiences as a core activity. To achieve this, an array of exhibitions (and supporting publications and public programs) were held, regionally, nationally and internationally. These included 'Through Our Eyes' at the Courthouse Gallery, Port Hedland (2008), the 'Canning Stock Route Project Olympic Showcase' at Perth Town Hall and Beijing International Olympic Expo, China ${ }^{23}$ (both 2008) and 'Telling Our Stories Through Painting' at Tjukurba Gallery, Wiluna (2009).24 Photography and multimedia from the project was exhibited in 2012 at the Australian Cultural Festival 'OzFest' in New Delhi, India, and also at the Social Work and Research Centre (known as the Barefoot College) in Tilonia, Rajasthan, India (FORM 2012). The exhibition program continues today, with the NMA producing a travelling photographic exhibition that opened in 
November 2014 at the Australian Consulate in Chengdu, China, followed by Taiwan's Australian embassy in early 2015. These are in addition to the success of the main 'Yiwarra Kuju' exhibition and national tour, which saw a total audience of over 314,000 .

In addition to these exhibitions, there are three major long-term legacy outcomes generated by the Canning Stock Route Project, the innovation of which has contributed to the Aboriginal and Torres Strait Islander arts sector's development. These include the One Road Multi-media post the exhibition's launch, the Indigenous Cultural and Intellectual Property (ICIP) processes surrounding the oral history and archive repository and the Digital Futures program that includes MIRA-Canning Stock Route Project Archive. ${ }^{25}$

\section{-PRoJect ARCHITECTURE AND THE POWER OF TEAMWORK}

The project's main processes, or production 'pillars', were built from Aboriginal knowledge systems and values, participatory and documentary arts practice, and collaborative content development and curation. These pillars also influenced the exhibition project's overall architecture, its scope, scale and story-telling dimension. Underscoring and binding the various production processes and content development streams was a hybrid mix of cultural, curatorial and anthropological methodologies, reinforced by the use of digital media. These processes were possible because of the diverse skills and experience of the project team.

The blend of these processes amalgamated a very organic, open and participatory approach, creating a safe, trusted space for all participants to emotionally connect. Participants were valued as people first rather than artistsevery person, every story was considered equally important regardless of whether their art was viewed as 'emerging' or 'established' by the contemporary Aboriginal art world.

The multiple architects of the project and exhibition (see Image 2) were responsible for coalescing these production processes. This project team came together through the return-to-Country trip along the Stock Route and continued to work in part- and full-time or casual capacities, in facilitating the community cultural relations, activities, events, workshops, exhibitions, oral histories, documentation and published outcomes. ${ }^{26}$ 
The passionate and highly motivated intercultural team was made up of emerging and established curators and multimedia practitioners, cultural advisors and arts, anthropological and community development workers with several having experience in a range of these areas and all having worked with Aboriginal communities out bush. Remote area people's professional interests, ambitions and skillsets influenced the project's direction. The team was responsible for various individual and collective relationships and consultations with the broader network of Aboriginal cultural leaders who guided the project and an additional network of Aboriginal people who assisted the project in multiple ways. ${ }^{27}$

FORM, with its array of skilled personnel, and co-producer the National Museum of Australia (NMA) supported this project team, who, in turn, emotionally and professionally supported each other while working closely alongside artists, cultural leaders and their families; listening, recording, producing, transcribing and curating content and travelling together.

As I described at the Same but Different forum, there is power in diversity. Diversity was the unifying ingredient for the project team members. Where possible, local people were employed in their own communities, travelled regionally and at times to Perth and Canberra, worked with family members and became spokespeople for the team. As the artists and team members reminded each other, it was essential to have a sense of humour and to welcome play; this sense of fun and adventure amped up the team and our interaction with participants and made the sometimes heavy task in carrying the history of the Western Desert physically and spiritually 'lighter'.

—ORAL HISTORIES, APPROVALS AND INTELLECTUAL PROPERTY

The overwhelming strength of the Project and exhibition project, for both contributors and visitors, was foregrounding Aboriginal stories told in Aboriginal voices.

Monique La Fontaine ${ }^{28}$

Over the project's four-and-a-half year research trajectory, over two hundred and forty interviews and oral histories were recorded by eleven team members. ${ }^{29}$ Central to shaping this content labyrinth, Aboriginal translators were tasked with 


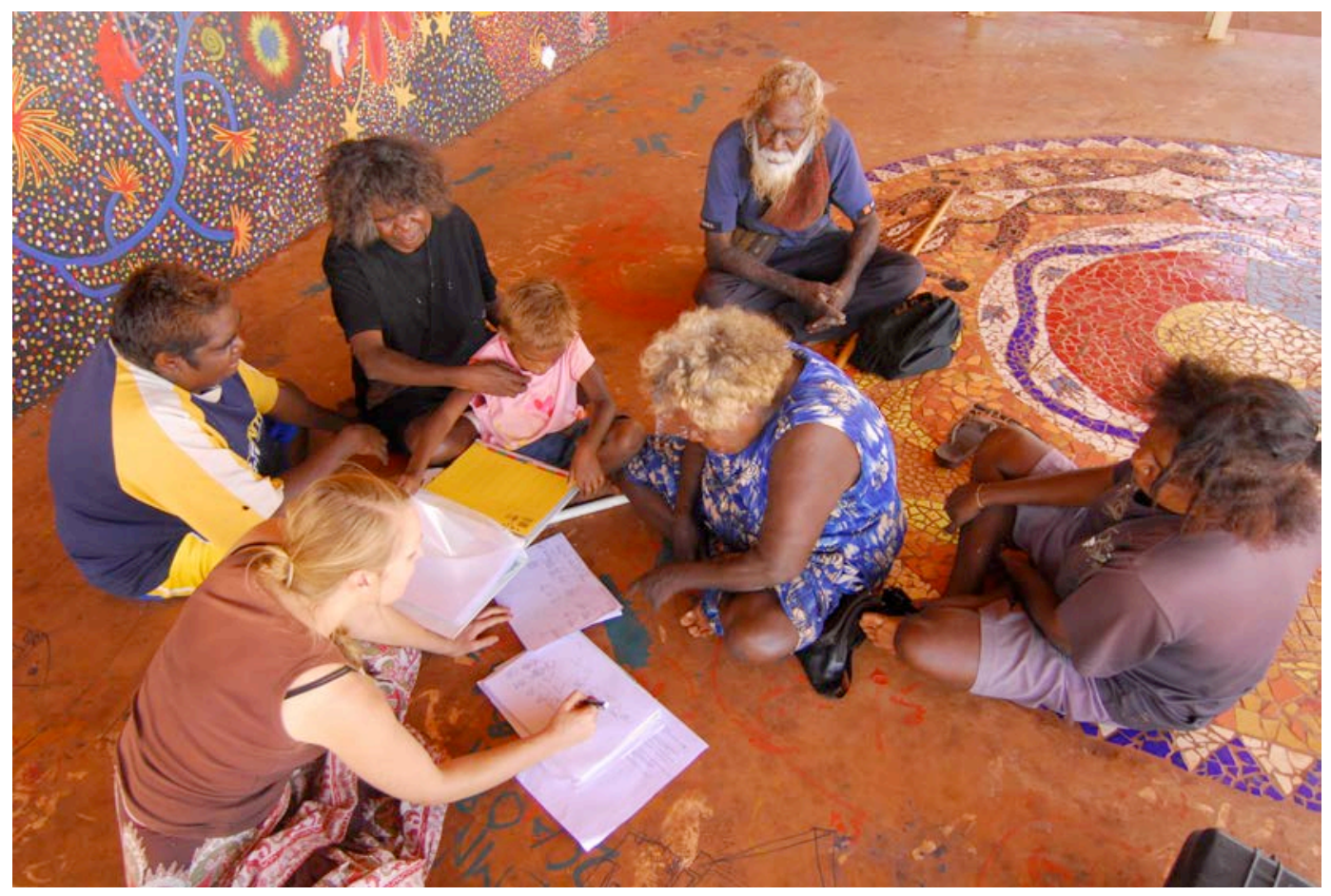

Image 10: Content Manager Monique La Fontaine with, from left to right, Therese Nowee, the late Brandy Tjungurrayi, Lucy Loomoo, Ann Nowee and family at Balgo 2009 (photograph: T. Acker; () FORM)

transcribing almost one hundred oral histories, recorded in more than ten languages, into English. This was a complex, slow and at times confusing process in managing content and in piecing together the genealogy puzzle within the matrix of Western Desert history. 30

The translations were then involved in the development of an Indigenous Cultural and Intellectual Property (ICIP) framework and consultative approvals process. This created a new partnership with the Arts Law Centre of Australia and built on the project's initial partner law firm, Herbert Smith Freehills. The project's ICIP protection of Aboriginal knowledge and decision making consisted of an enormous logistical 'one to one' communication and legal process that continued after the launch of 'Yiwarra Kuju' and into 2013. Twenty-seven approval meetings were held across the Western Desert with co-curators and the multimedia team, elders, senior advisors, artists and local decision makers, regarding the use of intellectual property and to protect Aboriginal knowledge systems. ${ }^{31}$ 


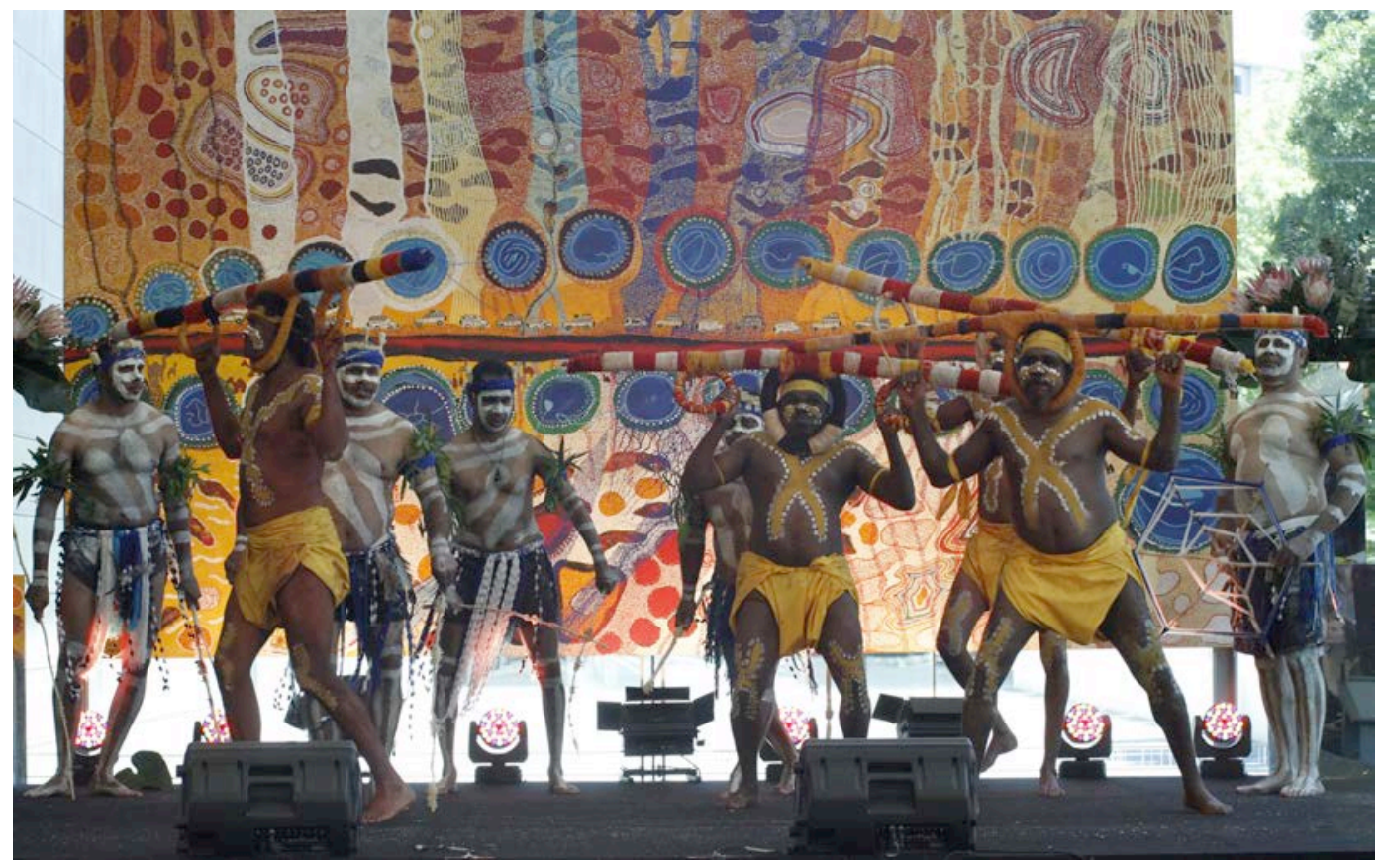

Image 11: KALAAC dancers (yellow) with Noongar dancers (blue) at Yiwarra Kuju exhibition launch, Perth 2011 (photograph: T. Acker; (C FORM)

When curators returned to communities with these detailed permission forms they were accompanied by a senior project translator and cultural advisor, most often Ngalangka Nola Taylor or Putuparri Tom Lawford, who interpreted and provided advice to elders and directed the non-Indigenous team in relation to culturally sensitive issues. 32

Mezgailis and La Fontaine acknowledge that this work expanded well beyond the exhibition's preparation processes and emphasised 'the importance of cultural leadership, collaboration and the recognition of legal and Indigenous rights'. ${ }^{33}$ The ICIP's innovative work expanded to embrace the Digital Futures program.

\section{-PROdUCING ONE RoAd MULTIMEDIA INTERACTIVE}

The One Road multimedia touchscreen interactive housed the bulk of the visual and audio material, and was by far the most daring and potentially risky aspect of the exhibition project. ${ }^{34}$ Using the footage of Ma and the emerging multimedia crew, it contained the 160 film vignettes of project activities and hundreds of photos, satellite images and 3D animation overlaying a digital version of Canning's original, hand-drawn map. 


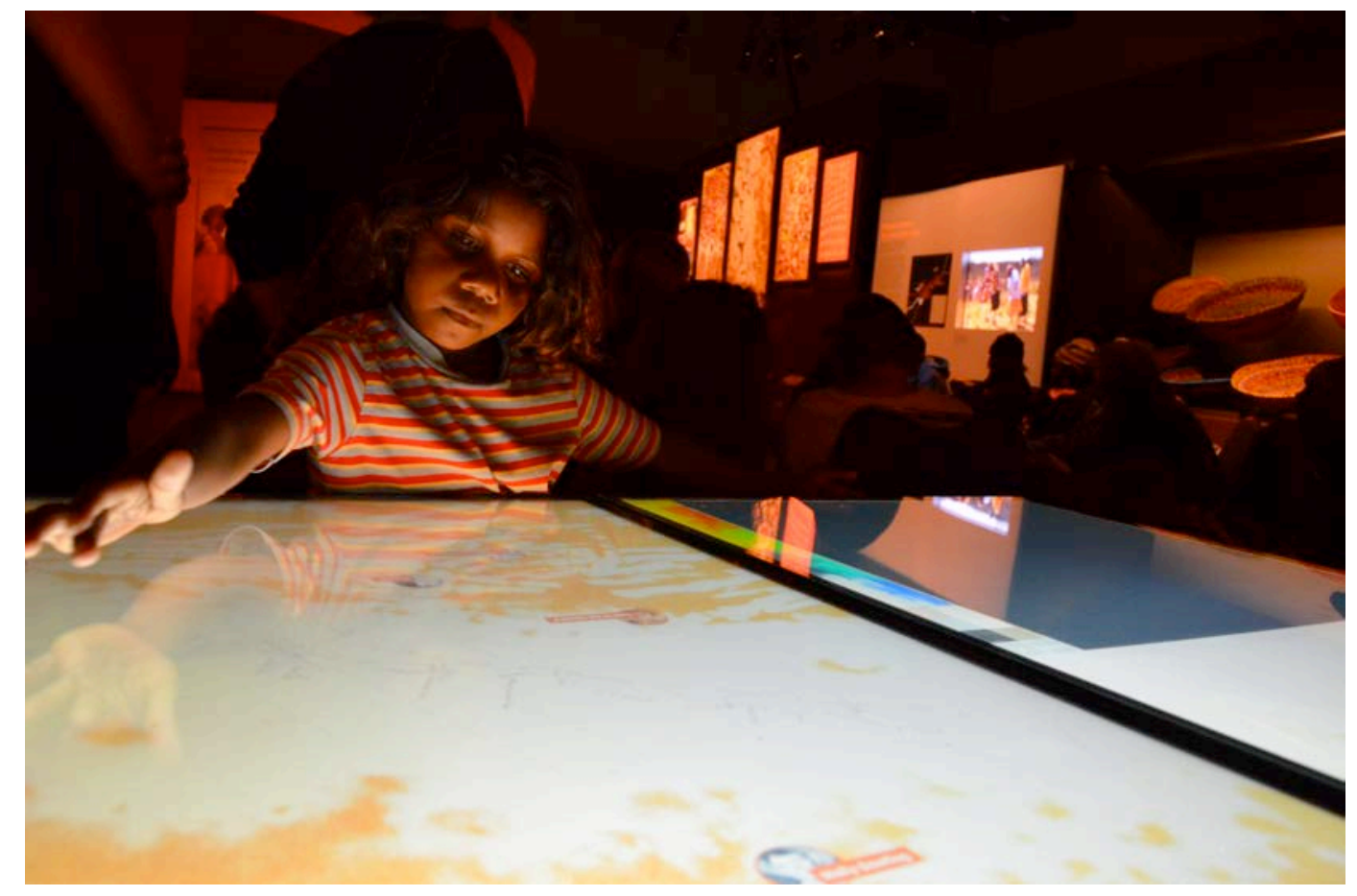

Image 12: Child exploring One Road multimedia interactive at 'Yiwarra Kuju' exhibition, Perth 2011 (photograph: T. Acker; @ FORM)

One Road was a first of its kind, produced under considerable time pressure. It defied the technical and financial risks it faced, resulting in a hugely successful outcome. Even the digital Rainbow Serpent and various animal animations were checked with artists and participants out bush to gauge their approval; the serpent's colours were, for example, adjusted to Fitzroy Crossing's elders' suggestion, so that 'he had the right powers'.

Using the project's digital media repository the NMA commissioned eleven short films which were dispersed at viewing stations throughout the exhibition. The emerging multimedia crew also produced several short films, a couple of which were made on the 'bush studio' of the Stock Route itself. ${ }^{35}$ These films were prominently featured in their own striking red theatrette inside the 'Yiwarra Kuju' exhibition.

Two-way professional development occurred between the project team, artists, art centres and the NMA's personnel for two years. These relationships have positively influenced the team and all those involved, the Aboriginal creative industries and community development sector at large: 'It is doubtful that any one 
partner could have delivered the exhibition to the same scale with the same level of engagement with artists and communities.'36

-DigitAL FUTUREs

Just like the old people, we are dreaming. We have a new dream with technology. We're using the newest technology with the oldest culture.

Curtis Taylor ${ }^{37}$

The decision to use digital media to capture stories at the project's outset transformed the endeavour and made it so much more than an art exhibition. ${ }^{38}$ Digital media fused with the ICIP process has allowed the project's content core to be grown from the inside out whilst establishing global best-practice in protecting intangible Aboriginal cultural heritage.

As I write this in late 2014, eight years on, the project's final miles are unfolding. ${ }^{9}$ Its total content repository amassed forty thousand cultural heritage items. This final stage is the Digital Futures program and is the last chapter in FORM's original commitment to Aboriginal participants, 'allowing them, their

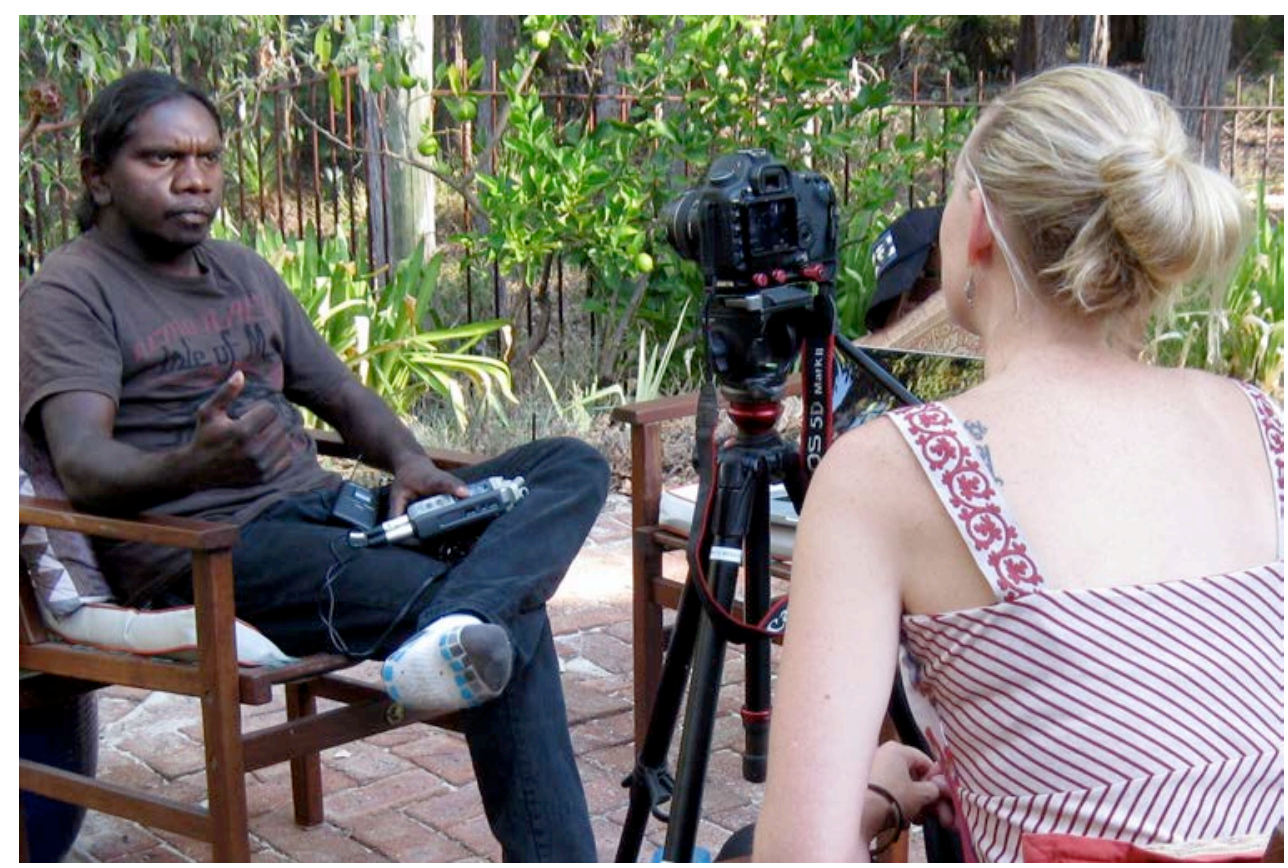

Image 13: Filmmaker Curtis Taylor talking with Carly Davenport Acker in Perth, March 2012, in preparation for the Same but Different inaugural forum (photo: T. Acker) 
families and extended communities ongoing access to their own increasingly valuable and vulnerable cultural heritage materials'.40 Digital Futures recently modified the One Road multimedia interactive content into an app and has pioneered the construction of MIRA Canning Stock Route Project Archive. ${ }^{41}$

This online format gives eight of the ten art centre partners instant access to One Road and the archive, as well as providing a hard drive of the material.

Aboriginal people are amongst the most researched peoples in the world, their cultural knowledge has been consistently removed from communities and deposited in distant institutions. While safely preserved in these locations, these kinds of records are notoriously difficult for people to access, creating a vacuum in communities that has radically impacted on the transmission of cultural knowledge between generations. ${ }^{42}$

With the first of four stages launched in late 2013, MIRA is a globally groundbreaking digital repatriation model that has been designed to manage the project's private and public content realms. Taylor suggested the name 'mira' which means 'to bring something hidden into the light' in Martu Wangka language. ${ }^{43}$ La Fontaine also states that MIRA and the ICIP repatriation process will encourage the making of new content from art centres and artists' own materials, from which they can benefit. ${ }^{4}$

National and international audiences will also be able to engage with the content, thereby directing new markets to art centres. The archive will assist in strengthening digital literacy, for young and old people. 45

To build the archive, FORM and the Centre for Digital Archaeology (CoDA) at the University of California, Berkeley in the United States established a partnership in 2012.46 Using CoDA's Mukurtu CMS, CoDA has created over one hundred and sixty indigenous archives around the world and the Canning Stock Route Project's content will be the largest that CoDA has been involved with. ${ }^{47}$

In addition to MIRA's production, Australian schools and national and international audiences are now able to access the award-winning One Road multimedia interactive in mobile app iOS (iPad and iPhone) and web versions. ${ }^{48}$ This large body of interpretive material is therefore available to local communities and people while they are actually travelling the Canning Stock Route. 
-SCALING UP, RISK AND SUCCESS

All kinds of serious obstructions and challenges were overcome throughout the project's development years. Navigating risk and uncertainty was standard operating procedure. The core team shouldered an array of pressures, from cultural obligations, cross-cultural communication issues to emotional worries and deadline fatigue and, notably, navigating between remote and urban life. In addition, FORM's project management team constantly worried over the project's finances as it expanded and significant new programming costs came to light. The global financial crisis of 2008 presented new challenges, though these were in part offset by the state's mining boom.

The project's needs and timelines often conflicted with the deadlines and requirements for 'Yiwarra Kuju' and at times also FORM's needs. Effectively, the team was producing aspects of the main project and exhibition project simultaneously while trying to ensure participants out bush were happy with the work and project development. The team straddled the contrasting domains of remote community life and urban-based work as well as the additional crosscultural layers and terrain, in order to ensure appropriate content management and approvals. The exhaustive scale and expense of these exercises was immense, fraught and unsustainable yet was prioritised as an essential process in order to appropriately consult artists equally and consistently through the project's and exhibition's milestones. These responsibilities and pressures took a toll on team members' personal wellbeing, especially as there were only two full-time employees throughout the project's duration and FORM struggled, yet managed, to raise essential salaries to sustain the larger team.

For the project to survive, and ultimately thrive, amalgamations formed with diverse partner and support agencies. A great deal of ingenuity was involved to secure the several million dollars of operational funds for both productions. Through the identification and alignment of shared incentives, these partnerships, a mixture of intellectual, in-kind and direct funding from government and private agencies, supported the main project and its exhibition project and bolstered the production of both. For a full acknowledgement list of both productions' partners and collaborators between 2006 and 2014, see key websites and the two major publications. ${ }^{49}$ 
Despite the immense efforts, energies and capital invested across the years, the cultural and creative outcomes are certainly worth it. What Pickering states about Yiwarra Kuju is also true for the Canning Stock Route Project:

Through the investment of all partners, the exhibition was a success for all involved. A success measured not just in terms of visitor numbers, but also in developing a model of ethical research and exhibition development. The collaboration provides a model for future museum practice and research in general, and will serve the Australian public, researchers and the Aboriginal communities from which the works are sourced for many years to come. ${ }^{50}$

-CONCLUSION

Stretching across Australia, from the remoteness of the Western Desert to the cities of Perth to Canberra, 'Yiwarra Kuju' resulted in multiple levels of success because of the genuine and trusted coproduction between the ten art centre enterprises, FORM and the NMA. At the heart of that trust was the collaboration and innovative processes of the Canning Stock Route Project. The exhibition integrated the project's multidisciplinary documentary research, art collection, content engineering, digital archive, remote and regional community participation and relationships, firstperson representation and ICIP engagement process, intercultural curatorial team, intellectual and financial partnerships, all of which, in turn, made the dynamic curation possible. The project's journey and significant outcomes have continued well beyond the exhibition, through the ICIP processes and Digital Futures archive program.

Together, the Canning Stock Route Project and 'Yiwarra Kuju' exhibition created a platform for Aboriginal artists, families, enterprises and communities to step forward, connect and contribute on their own terms. It demonstrates the possibilities of strong engagement with remote area Aboriginal peoples and cultures. The project's first-person representation, intergenerational and intercultural model has enabled mutual learning between remote and urban individuals and enterprises and illuminates culturally relevant methodologies for exchange. The result is a legacy that protects intangible cultural heritage and allows the narratives, identities and histories of the Western Desert to be shared by all. 
Carly Davenport Acker works at the intersection of the creative industries and cultural relations. She is a producer and curator with eighteen years' experience in arts education and community and cultural development across Australia. She is a Winston Churchill Fellow, awarded for her leadership in Indigenous education.

\section{-Notes}

${ }^{1}$ Curtis Taylor, Yarljyirrpa (Clever People), film transcript, 2012.

2 The project won the 2011 national Gold Award: Australian Business Arts Foundation (ABaF) Toyota

Community Awards, see

<http://www.creativepartnershipsaustralia.org.au/assets/goldbook2011.pdf>.

3 Curtis Taylor, Our Communities Together: Two-way Learning, dir. Curtis Taylor and Nicole Ma, short film, 2012.

4 Only an agile, not-for-profit organisation working with communities would naively dare to imagine, kick-start and attempt to sustain an initiative like the Canning Stock Route Project, especially with a socially inclusive approach that allowed new participants to be continually added.

${ }^{5}$ As I have described previously, this interest was the igniting force for the project's inception experienced by Tim and me when connecting with artists in Patjarr, Newman and Fitzroy Crossing in 2005. See Carly Davenport, 'The Journey is Everything: Ngurra Juju Walya-One Country, One PeopleThe Canning Stock Route', in M. La Fontaine and J. Carty, Ngurra Kuju Walyja, One Country One People: Stories from the Canning Stock Route, Macmillan Art Publishing, Melbourne, 2011, pp. 148-66.

6 BHP Billiton Iron Ore provided incentive the following year in mid-2007 in granting funds towards the endeavour to support the intended six-week trip along the stock route itself on proviso that FORM curate a show for the 2008 Beijing Olympics in China.

7 J. Carty, C. Davenport and M. La Fontaine, Yiwarra Kuju: The Canning Stock Route exhibition catalogue, National Museum of Australia, Canberra, 2010, p. 7.

8 J. Carty, 'Yiwarra Kuju: Turning Space into Place at the National Museum of Australia', in Laurent Jérôme (ed.), Anthropologie et Sociétés (special edition): 'Vues de l'Autre, images de Soi en muséographie: Matérialiser l'immatériel dans les musées', vol. 38, no. 3, 2014, p. 7.

9 The total documentation body generated by the project from 2006 to 2013 is 40,000 items-all being made accessible in 2014 and 2015 (to art centre partners, communities and the public) through the Digital Futures program.

10 By this stage, FORM had spent two years and repeated attempts to seek an institutional partnership to develop an exhibition and keeping place for the collection and content in perpetuity in Western 
Australia, first with the Western Australian Museum, then the Art Gallery of Western Australia, but it had not been able to secure one.

11 Much of the oral history content transcription and management continued into 2009 while the simultaneous curation of 'Yiwarra Kuju' began. This exhaustive process was led by La Fontaine and Carty, and Aboriginal cultural advisors Putuparri Tom Lawford and Ngalangka Nola Taylor in collaboration with Aboriginal translators Annette Williams, Wuntupayi Jane Gimme, Morika Biljabu, Hayley Atkins, Joshua Booth, Lena Long, Taji Desmond Taylor, Anne Nowee, Joy Nuggett, Gail Smiler, Daniel Walbidi, Martina Badal, Clifton Bieunderry, Lizzie Ellie, Suisie Gilbert, Nanan Hazel Hobbs, Olive Knight, George Lee, Gracie Mulligan, Eva Nagomarra and Dorothy Ward. They were supported by linguist and language consultants including Jessica Denniss, Sally Dixon, Eleonora Deak, Sue Hansen (Wangka Maya), Ken Hansen, Jan Mountney, Amee Glass, Joyce Hudson, Eirlys Richards, Lola Jones and Deanne Lightfoot.

12 Craddock Morton, director, NMA, 2008, <http://www.canningstockrouteproject.com/curating-thecollection/acquistion/>.

13 Michael Pickering, in conversation with the author.

${ }^{14}$ Michael Pickering, 'Picturing an Exhibition', in J. Carty and M. La Fontaine (eds), Ngurra Kuju Walyja: One Country, One People-Stories from the Canning Stock Route, FORM, Perth and Macmillan Art Publishing, Melbourn, 2011, p. 214).

15 See <www.glasfurdandwalker.com/Canning-Stock-Route-Project>.

16 'Yiwarra Kuju' was co-produced by FORM and the National Museum of Australia (30 July 2010 to 26 January 2011), then launched at the Perth Convention and Exhibition Centre as the cultural backdrop for CHOGM (October 2011) and opened to the public (2 to 27 November 2011). The exhibition travelled to Sydney and was shown at the Australian Museum (17 December 2011 to 29 April 2012). It was shown at the Queensland Museum in Brisbane (25 May 2013 to 14 July 2013). The touring program was managed by the NMA with funding support from the National Collecting Institutions Touring Outreach. See <www.canningstockrouteproject.com/yiwarra-kuju-exhibition/yiwarra-kujuthe-canning-stock-route>.

17 FRD's exhibition design reflected the team's chosen geographical curation using the four directions circling the stock route. Paintings were set back into walls and spot lit; inviting a personal and immersive encounter and 'story labels' (graphic tiles) housed artists' personal and biographical information. One of our most wild ideas was to portray the seven sisters canvases 'flying in the sky' and rigged from the ceiling, but we learnt to appreciate that this was not a sustainable design option. The exhibition's overall resonance was enhanced by FRD's respect for the project team's participatory processes. FRD created innovative design solutions which were then implemented by the team out bush directly with the artists. Artists were involved in the curation of the exhibition in unprecedented fashion, and provided feedback about how they saw their art work within the overall space. For more, see Carty, 'Yiwarra Kuju' and M. La Fontaine, 'Dreaming the Future: Mirrored Reflections and the use of 
Multimedia in the Canning Stock Route Project, in M. LaFontaine, and J. Carty (eds), Ngurra Kuju Walyja: One Country One People-Stories from the Canning Stock Route, Macmillan Art Publishing, Melbourne, 2011.

18 Jennifer Biddle 'Yiwarra Kuju The Canning Stock Route: Making (not Taking) History', Art Monthly Australia, vol. 8, August 2012, pp. 32-6; Jennifer Biddle, Remote Avant-Garde: Aboriginal Art under Occupation, Duke University Press, Durham and London, forthcoming 2015, Fontaine, 'Dreaming the Future' and Carty, 'Yiwarra Kuju'.

19 Biddle, Remote Avant-Garde.

20 Carty, 'Yiwarra Kuju', p. 3.

21 Ibid., p. 15.

22 This will become part of the Canning Stock Route visitor management, Draft Kuju Wangka Canning Stock Route Management Strategy, for the Wiluna and Birriliburu determination (pp. 1-15). The overall strategy was developed with all five traditional owner groups across the whole Canning Stock RouteWells 1-51 over a three-year period. Available at:

$<$ https://www.facebook.com/centraldesertlandandcommunity>.

23 Over 95,000 people visited the exhibition at the Expo in 2008.

${ }^{24}$ Each of these exhibitions were accompanied by catalogues and project publications produced by FORM and included two prospectus publications which were distributed to all participants and communities. FORM ensured that both major academic books were also presented to all participating artists in the Western Desert, as so often we had heard artists express their disappointment that external researchers, academics and visitors would not return to people or provide follow up in supplying artists with the printed 'end products' of their research. This was important as we did not wish to fall into the category of visitors that 'took but didn't give' especially as the project's development years were so long. ${ }^{25}$ See Biddle 'Yiwarra Kuju'; Biddle, Remote Avant-Garde; Fontaine, 'Dreaming the Future'; O. Mezgailis and M. La Fontaine, 'Yiwarra Kuju: The Canning Stock Route Casestudy', <http://www.artslaw.com.au/case-studies/entry/yiwarra-kuju-the-canning-stock-route/>; MIRA < www.mira.canningstockrouteproject.com $/>$. 26 People at the heart of the Project were Tim Acker (co-founder/ photographer/ executive support), Hayley Atkins (co-curator/translator), Morika Biljabu (filmmaker/ photographer/translator), Dr John Carty (co-curator/principal anthropologist/oral historian), Clint Dixon (filmmaker), Monique La Fontaine (content and collection manager/production editor/co-curator (2007-2011) and project manager (2011-2013), Putuparri Tom Lawford (cultural advisor/senior translator), Nicole Ma (multimedia director/mentor), 'KJ' Kenneth Martin (filmmaker), Doolmarria Louise Mengil (cocurator), Murungkurr Terry Murray (co-curator/translator), Curtis Taylor (filmmaker/translator), Ngalangka Nola Taylor (senior translator/project advisor) and myself (co-founder/project manager/co-curator). Pivotal in driving and sustaining the project, its exhibition program and 
exhibition project were Lynda Dorrington (FORM’s Executive Director) and Dr Michael Pickering. (Director, Aboriginal and Torres Strait Islander Program). Another seminal contributor was Wally Caruana (senior curator and mentor 2007-2008) who worked closely with the emerging co-curators to develop the Beijing Olympic Expo exhibition and finalisation of the Canning Stock Route Collection 27 Manmarr Daisy Andrews, Jakayu Biljabu, Joshua Booth, Joe Brown, Sandy Cox, Yanpiyarti Ned Cox, Kumpaya Girgaba, Kuji Rosie Goodjie, Jack Gordon, Jeffrey James, Milkujung Jewess James, Anga Friday Jones, Mayarn Julia Lawford, Ngarralja Tommy May, Jawarta Donald Moko, Yupinya Eubena Nampitjin, Billy Patch (Mr. P), Dadda Sampson, Muni Rita Simpson, Jukuja Dolly Snell, Ngilpirr Spider Snell, Geoffrey Stewart, Jawurji Mervyn Street, Jukuja Nora Tjookootja, Kamara Brandy Tjungurrayi, Patrick Olodoodi Tjungurrayi, Mantararr Rosie Williams, and Kilalapari Butcher Wise. The full extensive list of Aboriginal individuals, organisations and enterprise is listed in Carty and La Fontaine (eds), Ngurra Kuju Walyja: One Country One People, pp. 407-11).

28 FORM, Annual Report 2012, FORM, Perth, p. 224.

${ }^{29}$ La Fontaine, 'Dreaming the Future', p. 410.

${ }^{30} \mathrm{~A}$ process pioneered by Carty with support from La Fontaine.

31 FORM, Annual Report 2012.

${ }^{32}$ La Fontaine, 'Dreaming the Future', p. 223.

33 Mezgailis and La Fontaine, <http://www.artslaw.com.au/case-studies/entry/yiwarra-kuju-thecanning-stock-route/>.

34 Made possible by FORM winning the Major Production Fund in 2009 from the Department of Culture and the Arts, combined with NMA resources, One Road was produced by Nicole Ma Productions, FORM, the NMA and Lightwell < $<$ ww.lightwell.com.au/projects/yiwarra-kuju/ $>$ led the technological design. Freeman Ryan Design $<\underline{w w w . f r d . c o m . a u}>$ anchored its ten metre presence, as the show's signature piece. One Road won silver medal at the 2011 international MUSE Awards (USA) which recognises outstanding media and technology achievements in museum media. Available at:

<http://www.youtube.com/watch?v=XRZhzKAb4-Y>.

35 The project's 2011 DVD is available at Artfilms <www.artfilms.com.au/Detail.aspx?ItemID=4405>.

36 Pickering, 'Picturing an Exhibition', p. 214.

37 Curtis Taylor in La Fontaine, 'Dreaming the Future', p. 189).

${ }^{38}$ La Fontaine, 'Dreaming the Future', p. 207.

39 The driving force of FORM's Executive Director Lynda Dorrington continues, along with Mollie Hewitt (content assistant and curator 2010-2013, project manager 2013-present) and Travis Kelleher (MIRA data management, research and writing) are finalising the Digital Futures program and MIRA Canning Stock Route Archive.

40 FORM, Annual Report 2012, p. 65.

${ }^{41}$ Available at $<$ http://mira.canningstockrouteproject.com/>.

42 FORM, Annual Report 2012, p. 65. 
43 FORM website 2014, <www.form.net.au>.

44 M. La Fontaine, personal communication with the author, 2013.

45 M. La Fontaine, personal communication with the author, 2013.

${ }^{46}$ See $<$ www.codifi.info $>$.

47 M. La Fontaine, email correspondence with the author, 17 June 2013; FORM website, 2014, $<\underline{\text { www.form.net.au }}>$; see <www.mukurtu.org $>$.

${ }^{48} \mathrm{M}$. Hewitt, personal communication with the author, 2014; M. Hewitt in group email correspondence including the author, 1 Ausgust 2014. See: <https://itunes.apple.com/us/app/one-road-canning-stockroute/id708143626?ls=1\&mt=8> and < http://oneroad.canningstockrouteproject.com/>

49 The Canning Stock Route Project and 'Yiwarra Kuju' exhibition involved hundreds of contributors including arts and cultural centre staff; creative media and design partners; Aboriginal organisations; Aboriginal translators and cultural advisors; intercultural consultants and contributors; government and industry partners. See <www.canningstockrouteproject.com/collaborations/art-centres-creativepartners/> and <www.nma.gov.au/exhibitions/yiwarra_kuju/acknowledgements $>$ and Carty and La Fontaine, M. La Fontaine and J. Carty, Ngurra Kuju Walyja, One Country One People, p. 411.

50 Pickering, 'Picturing an Exhibition', p. 214.

\section{-BIBLIOGRAPHY}

Biddle, J., 'Yiwarra Kuju The Canning Stock Route: Making (not Taking) History', Art Monthly Australia, no. 8, August, 2012.

Biddle, J., Remote Avant-Garde: Aboriginal Art under Occupation, Duke University Press, Durham and London, forthcoming 2015.

Carty, J., 'West Side Story: Aboriginal Art History in the Canning Stock Route Country', in M. La Fontaine, and J. Carty (eds), Ngurra Kuju Walyja, One Country One People: Stories from the Canning Stock Route, Macmillan Art Publishing, Melbourne, 2011.

Carty, J., 'Yiwarra Kuju: Turning Space into Place at the National Museum of Australia', in L. Jérôme (ed.) Anthropologie et Sociétés (special edition): 'Vues de l'Autre, images de Soi en muséographie: Matérialiser l'immatériel dans les musées', vol. 38, no. 3, 2014.

Carty, J., C. Davenport and M. La Fontaine Yiwarra Kuju: The Canning Stock Route, exhibition catalogue, National Museum of Australia, Canberra, 2010.

Davenport, C., "The Story behind the Canning Stock Route Project, in J. Carty, C. Davenport and M. La Fontaine (eds), Yiwarra Kuju: The Canning Stock Route, exhibition catalogue, National Museum of Australia, Canberra, 2010.

Davenport, C., 'The Journey is Everything: Ngurra Juju Walya-One Country, One People-The Canning Stock Route', in M. La Fontaine, and J. Carty, Ngurra Kuju Walyja, One Country One People: Stories from the Canning Stock Route, Macmillan Art Publishing, Melbourne, 2011.

FORM, Annual Report 2012, FORM, Perth, 2012. 
La Fontaine, M. and J. Carty (eds), Ngurra Kuju Walyja, One Country One People: Stories from the Canning Stock Route, Macmillan Art Publishing, Melbourne, 2011.

La Fontaine, M., 'Dreaming the Future: Mirrored Reflections and the Use of Multimedia in the Canning Stock Route Project', in M. LaFontaine and J. Carty, Ngurra Kuju Walyja, One Country One People: Stories from the Canning Stock Route, Macmillan Art Publishing, Melbourne, 2011.

Mezgailis, O. and La Fontaine, M., 'Yiwarra Kuju: The Canning Stock Route Casestudy', <http://www.artslaw.com.au/case-studies/entry/yiwarra-kuju-the-canning-stock-route/>. Ngarralja, T.M, T.L. Putuparri and T.M. Murungkurr, 'Foreword', in J. Carty, C. Davenport and M. La Fontaine Yiwarra Kuju: The Canning Stock Route, exhibition catalogue, National Museum of Australia, Canberra, 2010.

'Ma La Koala', Newsletter of the Australian Consulate-General in Chengdu, no. 18, 7 November Australian Consulate-General, Chengdu, China, 2014.

Pickering, M. (2011) 'Picturing an Exhibition', in J. Carty and M. La Fontaine (eds), Ngurra Kuju Walyja, One Country, One People: Stories from the Canning Stock Route, Macmillan Art Publishing, Melbourne, 2011. 